\title{
Lack of TAK1 in dendritic cells inhibits the contact hypersensitivity response induced by trichloroethylene in local lymph node assay
}

Pan Yao ${ }^{\mathrm{a}, \mathrm{b}}$, Chu Hongqian ${ }^{\mathrm{a}, \mathrm{b}}$, Meng Qinghe ${ }^{\mathrm{a}, \mathrm{b}}$, Shang Lanqin ${ }^{\mathrm{a}, \mathrm{b}}$, Jiang Jianjun ${ }^{\mathrm{a}, \mathrm{b}}$, Yang Xiaohua ${ }^{\mathrm{a}, \mathrm{b}}$, Wei

$$
\text { Xuetao }^{\mathrm{a}, \mathrm{b}} \text {, and Hao Weidong }{ }^{\mathrm{a}, \mathrm{b}, *}
$$

${ }^{a}$ Department of Toxicology, School of Public Health, Peking University, Beijing, 100191, China

${ }^{\mathrm{b}}$ Beijing Key Laboratory of Toxicological Research and Risk Assessment for Food Safety, Beijing, 100191,

China

*corresponding author at: Department of Toxicology, School of Public Health, Peking University Health Science Center, 38 Xue Yuan Road, Hai Dian District, Beijing, 100191, China.

Tel: +86-10-82802352. Fax: +86-10-82802352. E-mail: whao@bjmu.edu.cn

Abbreviations: TCE, trichloroethylene; CHS, contact hypersensitivity; TAK1, transforming growth factor- $\beta$ activated kinase-1; DC, dendritic cell; LLNA, local lymph node assay; ACD, allergic contact dermatitis; DNFB, 2,4-dinirofluorobenzene. 


\section{Abstract:}

Trichloroethylene (TCE) is a ubiquitous environmental contaminant. Occupational TCE exposure has been associated with severe, generalized contact hypersensitivity (CHS) skin disorder. The development of CHS depends on innate and adaptive immune functions. Transforming growth factor- $\beta$ activated kinase- 1

(TAK1) controls the survival of dendritic cells (DCs) that affect the immune system homeostasis. We aimed to investigate the role of TAK1 activity in DC on TCE-induced CHS response. Control mice and DC-specific TAK1 deletion mice were treated with $80 \%$ (v/v) TCE using local lymph node assay (LLNA) to establish a TCE-induced CHS model. The draining lymph nodes (DLNs) were excised and the lymphocytes were measure for proliferation by BrdU-ELISA, T-cell phenotype analysis by flow cytometry and signaling pathway activation by western blot. The ears were harvested for histopathological analysis. Control mice in the $80 \%$ TCE group displayed an inflammatory response in the ears, increased lymphocyte proliferation, elevated regulatory T-cell and activated T-cell percentages, and more IFN- $\gamma$ producing CD8 ${ }^{+}$ T cells in DLNs. In contrast to control mice, DC-specific TAK1 deletion mice in the 80\% TCE group showed an abolished CHS response and this was associated with defective T-cell expansion, activation and IFN- $\gamma$ production. This effect may occur through Jnk and NF-אB signaling pathways. Overall, this study demonstrates a pivotal role of TAK1 in DCs in controlling TCE-induced CHS response and suggests that targeting TAK1 function in DCs may be a viable approach to preventing and treating TCE-related occupational health hazards.

Keywords: Trichloroethylene; transforming growth factor- $\beta$ activated kinase-1; dendritic cells; contact hypersensitivity; local lymph node assay 


\section{Introduction}

Trichloroethylene (TCE) is a chlorinated solvent that is widely used to clean and degrease metal parts.

Occupational exposure to TCE is associated with trichloroethylene hypersensitivity syndrome (THS). In the Guangdong Province in Southern China, 394 THS cases were diagnosed from 1988 - 2010 and its socio-economic impacts are numerous (Huang et al., 2006; Yongshun and Hanlin, 2010). THS is characterized by fever, generalized rash, liver dysfunction and superficial lymphadenopathy(Ministry of Health of the People's Republic of China, 2007). Previous studies have indicated that THS is probably a type IV (T-cell mediated or delayed-type) hypersensitivity, namely allergic contact dermatitis (ACD) (Nakayama et al., 1988; Watanabe et al., 2010).

The animal contact hypersensitivity (CHS) model is commonly used to study the pathophysiology of human ACD. In the CHS mouse model, the disorder is characterized by two phases: the sensitization and the elicitation phase (Saint-Mezard et al., 2004). During the sensitization phase, a hapten binds to endogenous proteins and activates antigen presenting cells, dendritic cells (DCs), residing in the skin (Jakob et al., 2001; Kaplan et al., 2012). Activated hapten-loading DCs migrate to the draining lymph nodes (DLNs), where antigen-specific T-cells are primed and clonally expanded (Honda et al., 2013). DCs are necessary for the initial CHS response. Therefore, inhibiting DC function may prevent the TCE-induced CHS response. The murine local lymph node assay (LLNA) is recognized as a stand-alone method to determine the skin sensitizing potential of chemicals (Takeyoshi et al., 2006). It has been incorporated into official test guidelines, among those published by the Organization for Economic Cooperation and Development (OECD, 2010). LLNA studies the sensitization phase of CHS and provides quantitative data for chemical sensitization potential assessment. As DCs play a central role in the sensitization phase, we chose LLNA to establish the TCE-induced CHS model and study the effect of DC on it. 
Transforming growth factor- $\beta$ (TGF- $\beta$ )-activated kinase-1 (TAK1, encoded by Map3k7) belongs to the mitogen-activated protein kinase kinase kinase (MAP3K) family and is widely accepted as a key molecule in the pro-inflammatory signaling pathway, including interleukin-1 (IL-1), tumor necrosis factor- $\alpha$ (TNF- $\alpha$ ), and toll-like receptor (TLR) (Ninomiya-Tsuji et al., 1999; Sakurai et al., 1998; Shirakabe et al., 1997). TAK1 plays differential regulatory roles in innate immune cells, such as DCs (Wang et al., 2012), macrophages (Kawai and Akira, 2011), natural killer (NK) cells (Rajasekaran et al., 2011) and neutrophils (Ajibade et al., 2012). It is also a critical mediator of the inflammatory response

(Kajino-Sakamoto et al., 2008; Omori et al., 2006; Sato, 2006). 5Z-7-oxozeaenol, a resorcyclic lactone, first reported as a highly potent chemical inhibitor of TAK1, can inhibit picryl chloride (PC)-induced ear swelling (Ninomiya-Tsuji et al., 2003). Moreover, our previous study demonstrated that TAK1 deficiency in DCs leads to a decrease in the 2,4-dinitrofluorobenzene (DNFB) -elicited CHS in the ear (Zhao et al., 2011). Thus, we hypothesize that inhibiting TAK1 function in DCs could suppress the TCE-induced CHS response.

This study aimed to investigate the effect of TAK1 function in DCs on the TCE-induced CHS response. The LLNA was used to establish the TCE-induced CHS model, and DC-specific TAK1 deletion mice were used to study TAK1 activity in DCs. The results showed that TAK1 function in DC may be essential for TCE-induced CHS development and T-cell effector function, and NF-אB and MAPK-Jnk signaling pathway may be involved. These results suggest that DC-specific targeting of TAK1 may be a feasible therapeutic treatment for the TCE-induced occupational health hazard.

\section{Materials and Methods}

Mice

Floxed Map3k7 (Map3k $7^{71 / f 1}$ ) and CD11c-Cre mice were purchased from the Jackson Laboratory (Bar 
Harbor, ME, USA). All mice were on C57BL/6 background and were housed in a barrier system (temperature: $20-26^{\circ} \mathrm{C}$; relative humidity: $40-70 \%$ ) with a $12 \mathrm{~h}$ light/dark cycle. Water and standard diet were available ad libitum. The study was approved by the Animal Experimental Welfare \& Ethical Inspection Committee of Peking University according to the laboratory animal administration rules of the Ministry of Science and Technology of the People's Republic of China.

\section{Chemicals}

Trichloroethylene (TCE, purity $>99 \%$ ) and 2,4-dinirofluorobenzene (DNFB, purity $>99 \%$ ) were obtained from Sinopharm Chemical Reagent Co., Ltd (Shanghai, China). TCE and DNFB were both dissolved in the recommended vehicle AOO. AOO is a 4:1 mixture of acetone and olive oil (4:1 acetone/ olive oil). 5-Bromo-2'-deoxyuridine (BrdU, Sigma-Aldrich) was dissolved in phosphate-buffered solution (PBS) to achieve a final dose of $5 \mathrm{mg} / \mathrm{animal}$ in a $0.5 \mathrm{ml}$ injection.

\section{Cell purification}

$\mathrm{CD}^{+} \mathrm{T}$ cells from $\mathrm{CON}$ and $M a p 3 k 7^{\mathrm{DC}}$ mice were isolated by negative selection using the mouse $\mathrm{CD}^{+} \mathrm{T}$ cell isolation kit (Stem Cell Technologies, Canada), according to the manufacturer's protocol. Purity of the sorted cells was $>95 \%$ as confirmed by flow cytometry. CD $11 \mathrm{c}^{+}$DCs were isolated using the mouse CD11c positive selection kit (Stem Cell Technologies, Canada) according to the manufacturer's instruction. Purity of the isolated CD11 $\mathrm{c}^{+}$DCs was $>90 \%$ based on flow cytometry analysis.

\section{Gene expression analysis}

Total RNA was extracted from $\mathrm{CD} 4^{+} \mathrm{T}$ cells or $\mathrm{CD} 11 \mathrm{c}^{+} \mathrm{DCs}$ using TRIzol reagent (Transgen Biotech, Beijing, China), according to the manufacturer's instruction. Total RNA $(1 \mu \mathrm{g})$ was reverse transcribed with Oligo dT primer to cDNA using PrimeScript ${ }^{\mathrm{TM}}$ RT-PCR kit (Takara, Japan). The primer- probe sets used in this study were mouse Map3k7 (assay ID: Mm00554514_m1) and GAPDH (assay ID: 
Mm99999915_g1) purchased from Applied Biosystems (Carlsbad, CA, USA). These real-time PCR reactions were carried out using Premix Ex Taq ${ }^{\mathrm{TM}}$ (Probe qPCR) (Takara, Japan) and the IQ5 iCycler (Bio-Rad Laboratories), according to the manufacturer's protocols. The relative gene expression was calculated using the delta-delta $\mathrm{Ct}$ (threshold cycle) method based on normalization to the reference gene Gapdh (glyceraldehyde-3-phosphate dehydrogenase).

\section{LLNA and measurement of lymphocyte proliferation}

LLNA: BrdU-ELISA was conducted according to the OECD test guideline (no. 442B) (OECD, 2010). Briefly, female mice (6-8 weeks) of each phenotype were assigned randomly to each group. Mice were exposed topically on the dorsum of both ears to $25 \mu \mathrm{l}$ of $80 \%$ (v/v) TCE, $0.1 \%(\mathrm{v} / \mathrm{v})$ DNFB (positive control) and AOO (vehicle control) alone daily for three consecutive days (i.e., Days 1-3). All mice were then injected intraperitoneally with $0.5 \mathrm{ml}(5 \mathrm{mg} /$ mouse $)$ of BrdU $(10 \mathrm{mg} / \mathrm{ml})$ solution on Day 5 .

Approximately $24 \mathrm{~h}$ after BrdU injection, animals were humanely sacrificed, and auricular DLNs were excised.

The excised right and left auricular lymph nodes were pooled for each animal and a single-cell suspension was prepared by gentle mechanical disaggregation in PBS and filtration through a 70 $\mu$ m nylon cell strainer (Falcon). The cells were washed twice with PBS at $4^{\circ} \mathrm{C}$ and then re-suspended in $15 \mathrm{ml}$ of PBS. The lymphocyte numbers were counted using a hemocytometer. The extent of BrdU incorporation was then measured using a BrdU cell proliferation ELISA kit (Roche, Mannheim, Germany, Cat No: 1164722901), according to the manufacturer's instructions. Absorbance at $370 \mathrm{~nm}$ with a reference wavelength of $492 \mathrm{~nm}$ was determined with a microplate reader (BMG Labtech). The BrdU labeling index was defined by the equation: $\mathrm{BrdU}$ labeling index $=\left(\mathrm{ABS}_{370}-\mathrm{ABS}\right.$ blank $\left._{370}\right)-\left(\mathrm{ABS}_{492}-\mathrm{ABS}\right.$ blank $\left._{492}\right)$.

The stimulation index (SI) for each group was derived by dividing the mean BrdU labeling 
index/mouse within the $80 \%$ TCE and $0.1 \%$ DNFB groups by the mean BrdU labeling index for the AOO group. The average SI for the vehicle control was then equal to one.

\section{Histopathological analysis}

After the animals were sacrificed, $132 \mathrm{~mm}^{2}$ of the ears was punched, fixed with $10 \%$ formaldehyde and embedded in paraffin. Then $5 \mu \mathrm{m}$ sections were cut from each sample and stained with hematoxylin and eosin (HE). All sections were observed using a light microscope (Nikon E400, Japan).

\section{Staining for cell surface markers and Foxp3}

The single-cell suspension of auricular lymph nodes was prepared as stated in the LLNA section and aliquots of $10^{6}$ cells were incubated with each cell surface fluorescence-conjugated monoclonal antibodies for $0.5 \mathrm{~h}$ at $4{ }^{\circ} \mathrm{C}$ in the dark. Excessive unreacted antibody was removed by washing the cells with staining buffer. Intracellular Foxp3 was stained using the Foxp3 staining buffer set (eBioscience, San Diego, CA, USA) according to the manufacturer's protocols.

\section{Stimulation of cytokine production and intracellular cytokine staining}

The single-cell suspension of auricular lymph nodes was prepared as stated in the LLNA section and aliquots of $2 \times 10^{6}$ cells were stimulated with cell stimulation cocktail $(500 \times, 40.5 \mu \mathrm{M} 12$-myristate 13-acetate [PMA] and $670 \mu \mathrm{M}$ ionomycin in ethanol, eBioscience) for $4 \mathrm{~h}$ in the presence of Brefeldin A (1000 ×, eBioscience). The cells were stimulated in RPMI 1640 medium (Gibco) supplemented with 10\% fetal bovine serum, $1 \%$ penicillin/streptomycin , $2 \mathrm{mM}$ l-glutamine and 50 $\mathrm{MM}$ 2-mercaptoethanol and incubated under a humidified atmosphere of $5 \% \mathrm{CO}_{2} / 95 \%$ air at $37^{\circ} \mathrm{C}$. Different cell surface markers and intracellular cytokines were stained with cocktails of fluorescence-conjugated monoclonal antibodies according to the manufacturer's protocols (eBioscience).

\section{Flow cytometry analysis}


Fluorescence-conjugated monoclonal antibodies, including anti-mouse CD4 FITC, anti-human/mouse CD44 FITC, anti-mouse IFN- $\gamma$ FITC, anti-mouse/rat Foxp3 FITC, anti-mouse B220 PE, anti-mouse CD62L PE, anti-mouse IL-4 PE, anti-mouse CD25 PE, anti-mouse CD3e PE-Cy ${ }^{\mathrm{TM}}$ 5, anti-mouse CD4 PE-Cy ${ }^{\mathrm{TM}} 5$ and anti-mouse CD8a PE-Cyanine7, were purchased from eBioscience (San Diego, CA, USA). Flow cytometry analysis of labeled cells was performed on an FC500-MPL flow cytometry (Beckman Coulter). A minimum of 20000 events/ sample was collected and analyzed for antigen expression. Nonviable cells, based on low forward scatter and side scatter, were excluded from each sample. Data analysis was performed with the use of FlowJo 7.6.1 software.

\section{Western blot analysis}

Lymphocytes were isolated from DLNs and lysed with cold Western and IP cell lysis buffer (Beyotime Biotechnology Co. Ltd, Shanghai, China). Protein concentrations were determined using the bicinchoninic acid protein assay (Beyotime Biotechnology Co. Ltd, Shanghai, China). Approximately $15 \mu \mathrm{g}$ of protein was electrophorized in 8-12\% SDS-PAGE gel and then transferred to nitrocellulose membranes. The nitrocellulose membranes were blocked in 5\% skim milk (w/v) in tris-buffered saline (TBS) with $0.1 \%$ tween-20 for $2 \mathrm{~h}$ at room temperature and incubated overnight at $4{ }^{\circ} \mathrm{C}$ with indicated primary antibodies, including p-p38, p38, p-Jnk, Jnk, p-Ikk $\alpha / \beta(\operatorname{Ser176/180),~p-~I~\kappa B~} \alpha$ and I $\kappa B \alpha$ antibodies (Cell Signaling, Danvers, MA). The mouse $\beta$-actin antibody (Santa Cruz Biotechnology, Santa Cruz, CA, USA) was used as a loading control. After three washes, the membranes were incubated with secondary antibody for $2 \mathrm{~h}$ at room temperature. The sample protein on the nitrocellulose membranes were detected by chemiluminescence using the ECL-plus kit (GE Health, USA). All experiments were performed independently at least three times.

\section{Statistical analysis}


Statistical analysis was performed using GraphPad Prism software (GraphPad, La Jolla, CA). Data are expressed as mean \pm standard deviation (SD). Statistical significance among the data from various groups was determined using a Student's $t$-test. Statistics with $p$ value $<0.05$ were considered significant.

\section{Results}

\section{TAK1 deficiency in DCs suppressed the development of TCE-induced CHS response}

To study the role of TAK1 in DCs in controlling the CHS in response to TCE, we crossed Map $3 k 7^{\mathrm{fl} / \mathrm{fl}}$ mice with CD11c-Cre mice to delete the floxed Map3k7 allele specifically in DCs (referred to as "Map3k7 mice" hereafter). Control mice were in the same genetic background and included CD11c-Cre to account for Cre effects (referred to as "CON mice" hereafter). The TAK1 mRNA expression level in splenic DCs from Map3k $37^{\mathrm{DC}}$ mice decreased compared to that of $\mathrm{CON}$ mice, but remained intact in $\mathrm{CD} 4^{+}$ T cells (Figure 1).

LLNA, a stand-alone method for examining ACD (Choi et al., 2013), was performed to elicit a TCE-induced CHS response in CON and Map3k $37^{\mathrm{DC}}$ mice. During the study, none of the mice showed overt irritation, as indicated by ear swelling and redness. There was no systemic toxicity as assessed by change in body weight, behavior and clinical signs of illness in any of the treatment groups (data not shown). DNFB is a well-known strong contact sensitizer and was used in this study as the positive control substance to validate the performance of the assay. The sensitizing capacity of TCE assessed by LLNA has been previously determined in C57BL/6 mice in our lab (Supplementary Table 1). The results showed that TCE increased lymphocyte proliferation in DLNs in a dose-dependent manner and 80\% TCE exhibited the most potential to cause sensitization. Hence, in this study we chose an $80 \%$ TCE dose to induce CHS using LLNA. While a CHS response was effectively induced by TCE in CON mice with SI value of $2.81 \pm 0.29$ (Figure 2A), greater than the 1.6 SI cut-off value, $\operatorname{Map} 3 k 7^{\mathrm{DC}}$ mice failed to elicit the lymphocyte 
proliferation in DLNs in TCE treatment as the SI value $(1.03 \pm 0.20)$ was less than 1.6 (Figure 2A). The total lymphocyte number of DLNs was elevated in CON mice with ongoing TCE-induced CHS. However, this increase was impaired in Map3k $7^{\mathrm{DC}}$ mice given the same treatment (Figure 2B).These results suggested that DCs might require TAK1 to control lymphocyte proliferation during the sensitization phase of the TCE-induced CHS response. The histopathological analysis also demonstrated that the TCE-induced increase in epidermal thickness and leukocyte infiltration into the dermis of CON mice was suppressed by DC-specific TAK1 deficiency, indicating that lack of TAK1 in DCs inhibits the skin inflammatory response to TCE (Figure 2C).

TAK1 function in DCs was essential to maintain the homeostasis of T cells in the TCE-induced CHS response

We then assessed the accumulation of T- and B-cell populations in DLNs of CON and Map $3 k 7^{\mathrm{DC}}$ mice in response to TCE, as the TCE-induced CHS response is categorized as a T-cell mediated delayed-type hypersensitivity reaction (Chen et al., 2006; Kaneko et al., 2000). The results showed that Map3k7DC mice had decreased percentages of $\mathrm{T}$ cells, particularly $\mathrm{CD} 8^{+} \mathrm{T}$ cells in peripheral lymph nodes, compared with CON mice (Figure 3A, B). The number of $\mathrm{T}$ cells, $\mathrm{CD} 4^{+} \mathrm{T}$ cells and $\mathrm{CD} 8^{+} \mathrm{T}$ cells in DLNs of TCE-treated CON mice was increased in comparison with AOO-treated CON mice (Figure 3A, B). In contrast, such an increase did not occur in Map3k $7^{\mathrm{DC}}$ mice (Figure 3A, B). The proportion and number of B-cells showed an increased trend but was not statistically significant in Map3k $7^{\mathrm{DC}}$ mice (Figure $\left.3 \mathrm{~A}\right)$. The decreased percentages of T-cell populations and increased percentage of B-cell population in DLNs of CON mice in the $80 \%$ TCE group did not appear in the DLNs of Map3k $7^{\mathrm{DC}}$ mice in the same group (Figure 3A, B). In addition, Treg cell numbers were considerably decreased in the DLNs of Map3k $7^{\mathrm{DC}}$ mice, suggesting normal TAK1 function in DCs has a critical role in promoting Treg cell generation, 
which did not accumulate in response to TCE but did accumulate in CON mice (Figure 3C). These findings demonstrate that defective TAK1 function in DCs influences T-cell homeostasis and expansion during the sensitization phase of the TCE-induced CHS response.

Intact TAK1 in DCs was critical to promoting T-cell priming during the TCE-induced CHS response

During the sensitization phase, hapten-bearing DCs migrate from the skin to the DLNs where hapten-specific T-cells are generated and primed (Saint-Mezard et al., 2004). We further studied whether T-cell activation and effector T-cell cytokine production were affected by TAK1 deletion in DCs during TCE-induced CHS development. In response to $80 \%$ TCE, the frequency of $\mathrm{CD}^{+}$and $\mathrm{CD} 8^{+} \mathrm{T}$ cells with an activated phenotype (CD62 $\left.\mathrm{L}^{\text {low }} \mathrm{CD} 44^{\text {high }}\right)$ in the DLNs from CON mice increased significantly, but such T-cell activation abrogated in Map3k $7^{\mathrm{DC}}$ mice (Figure 4A, B). We concluded thatTAK1 may have a critical role in DCs for T-cell activation during the TCE-induced CHS.

Furthermore, we assessed the cytokine production of $\mathrm{T}$ cells in $\mathrm{CON}$ and Map3k $7^{\mathrm{DC}}$ mice undergoing the TCE-induced CHS response. Consistent with the T-cell activated status, although a large proportion of IFN- $\gamma$-secretion $\mathrm{CD}^{+} \mathrm{T}$ cells were detected in the DLNs of CON mice in the $80 \%$ TCE group, $\mathrm{CD} 8^{+} \mathrm{T}$ cells from Map $3 k 7^{\mathrm{DC}}$ mice failed to secrete more IFN- $\gamma$ with the same treatment (Figure 4C). Similarly, $\mathrm{CD}^{+} \mathrm{T}$ cells in Map $3 k 7^{\mathrm{DC}}$ mice did not secrete enhanced levels of IFN- $\gamma$ when sensitized with TCE (Figure 4D). Collectively, these results showed that intact TAK1 in DCs may be important for T-cell priming in the TCE-induced CHS response.

Effect of DC-specific TAK1 deletion on MAPK and NF-kB signaling pathways during the TCE-induced CHS response

To further elucidate the molecular mechanism underlying the inhibitory effect of TAK1 deficiency in DCs on TCE-induced CHS response, we investigated MAPK activation, including p38 and Jnk, and 


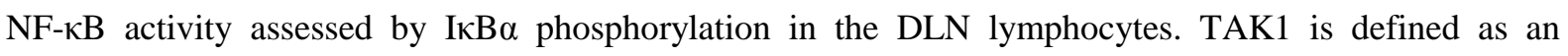
activating kinase for the IкB kinase (IKK) complex (Ninomiya-Tsuji et al., 1999; Sakurai et al., 1999). Hence, we also detected Ikk $\alpha / \beta$ phosphorylation. Treatment with $80 \%$ TCE induced strong activation of Jnk but not $\mathrm{p} 38$ or the NF- $\mathrm{kB}$ pathway in CON mice, while DC-specific TAK1 deficiency abolished the TCE-mediated phosphorylation of Jnk (Figure 5). The expression of p-p38 was minimally affected by TAK1 deletion in DCs (Figure 5). However, the lack of TAK1 in DCs caused considerably diminished phosphorylation of IkB $\alpha$ and Ikk $\alpha / \beta$ (Figure 5). Moreover, these results indicated that DC-specific loss of TAK1 inhibited the TCE-induced CHS response through the Jnk-MAPK pathway and TAK1 function in DCs may be essential to mediate NF- $\mathrm{BB}$ activation in DLNs.

\section{Discussion}

TCE-induced skin disorders were first described in a US textbook published before the 1950s and first appeared in Asia after the mid-1990s (Watanabe, 2011). In the past 20 years, an increasing number of THS patients have been reported in TCE-exposed laborers in China (Huang et al., 2012; Kamijima et al., 2007; Kamijima et al., 2008; Xu et al., 2009) and this has become a severe occupational health hazard that requires effective prevention and treatment approaches. Abandoning the use of TCE is not currently practical which makes it difficult to avoid TCE exposure. However, the side effects of current drugs to treat THS, such as corticosteroids, have attracted considerable attention. Improved treatment methods from the perspectives of efficacy and side effects are needed. Protein kinases in proinflammatory signaling cascades are promising molecular targets for therapeutic interventions of inflammatory disorders (Adcock et al., 2006). TAK1 has been characterized as a key regulator in inflammatory and immune signaling pathways (Sakurai, 2012). Previously, TAK1 deletion suppressed renal inflammation (Ma et al., 2011) and rheumatoid arthritis (Hammaker et al., 2007). Moreover, studies have indicated that TAK1 is involved in 
CHS development elicited by DNFB or PC (Ninomiya-Tsuji et al., 2003; Zhao et al., 2011). The present study demonstrates that CHS induction and T-cell priming by TCE may rely on intact TAK1 function in DC.

The LLNA is one of the standard methods used to identify the potential to induce CHS of chemicals (van den Berg et al., 2005), having an objective end point- measure the proliferative response of cells in the DLNs during the sensitization phase in naïve animals (Anderson et al., 2011; Kimber et al., 2002). Compared to traditional guinea pig assays, LLNA shares many advantages: conforming to the " $3 \mathrm{R}$ principle", shorter experimental cycle and quantitative endpoint (Basketter et al., 2007; Haneke et al., 2001; Sailstad et al., 2001).In addition, measurement of immunophenotypic parameters can also be involved (Gerberick et al., 1999; Humphreys et al., 2003). In our previous study, we observed that TCE exhibited a significant dose-dependent increase of the SI values in LLNA and the highest dose used in the study- $80 \%$ showed the strongest allergic effect (Supplementary Table 1). To establish a reliable and reproducible TCE-induced CHS model, we also used $80 \%$ TCE in the present study. The SI value and total lymphocyte number in the DLNs of the $80 \%$ TCE group dramatically increased compared to the AOO vehicle control group in the CON mice (Figure 2A,B). Histopathological analysis of the ear sections from the $80 \%$ TCE group displayed epidermal thickening and inflammatory cell infiltration into the dermis (Figure 2C). These results indicated that a TCE-induced CHS model by the means of LLNA was successfully established in the current study. We further analyzed the lymphocyte subpopulations in DLNs in this TCE-induced CHS model and observed a decrease in the percentage of total T cells $\left(\mathrm{CD}^{+}\right)$as well as $\mathrm{CD} 4^{+}$and $\mathrm{CD} 8^{+}$cells and an increase in the percentage of $\mathrm{B}$ cells $\left(\mathrm{B} 220^{+}\right)$compared to the $\mathrm{AOO}$ group (Figure 3A, B), which are characteristic for allergens (Hariya et al., 1999; Sikorski et al., 1996). Then, we assessed the activation and production of type 1 cytokine (IFN- $\gamma$ ) and type 2 cytokine (IL-4) by CD4 ${ }^{+}$ 
and $\mathrm{CD}^{+} \mathrm{T}$ cells in DLNs of this model. CD62L is a lymph node homing receptor expressed at the surface on naive $\mathrm{T}$ cells. CD62L is rapidly down-regulated from the cell surface following T-cell activation. CD44 proteins are involved in cell- cell interactions, cell adhesion and migration, and is up-regulated at the T-cell surface following T-cell activation. Thus, $\mathrm{CD} 62 \mathrm{~L}^{\text {low }} \mathrm{CD} 44^{\text {high }} \mathrm{T}$ cells represent recently activated $\mathrm{T}$ cell (Gerberick et al., 1997). In the $80 \%$ TCE group, the percentages of activated $\mathrm{CD} 4^{+}$and $\mathrm{CD} 8^{+} \mathrm{T}$ cells in DLNs were much higher than that in the AOO group (Figure 4A,B), which showed that T-cell activation was induced by TCE in the CHS model. The priming of hapten-specific IFN- $\gamma$-producing $\mathrm{CD}^{+} \mathrm{T}^{-}$cells in DLNs is key events occurring in the sensitization phase of CHS after skin contact with a hapten (Saint-Mezard et al., 2004). We observed that over $25 \%$ of IFN- $\gamma^{+} \mathrm{CD} 8^{+} \mathrm{T}$ cells in DLNs were detected in CON mice sensitized with TCE (Figure 4C), while only approximately $2 \%$ of IFN- $\gamma^{+} \mathrm{CD} 4^{+} \mathrm{T}$ cells were seen (Figure 4D), suggesting that $\mathrm{CD} 8^{+} \mathrm{T}$ cells contributed to the majority of IFN- $\gamma$ production during the development of the TCE-induced CHS response. However, the percentages of IL- $4^{+} \mathrm{CD} 4^{+}$and IL- $4^{+} \mathrm{CD} 8^{+}$ T cells in DLNs did not altered with TCE treatment in CON mice (Figure 4C, D). Collectively, the findings demonstrated that TCE-induced CHS can be classified as a T helper type 1 (Th1) response similar to DNFB- (Th1 hapten) elicited CHS (Gorbachev and Fairchild, 2001).

DCs, the main APCs in the sensitization phase of CHS, play a pivotal role in initiating the immune response to haptens, which is to capture antigens, migrate to DLNs and present antigens to activate naïve T cells in DLNs (Christensen and Haase, 2012; Honda et al., 2013). It has been reported that TAK1 is an essential regulator of DC survival and immune system homeostasis and function (Wang et al., 2012). To assess the requirement for TAK1 in DCs to promote TCE-induced CHS response, we generated mice with loxP-flanked Map3k7alleles that also expressed Cre recombinase from the DC-specific gene Cd11c (Map $3 k 7^{\mathrm{DC}}$ mice). The result demonstrated that TAK1 was specifically knocked out in DCs but not in other 
immune cell types, such as $\mathrm{CD} 4^{+} \mathrm{T}$ cells (Figure 1). During the sensitization phase of CHS, quantitative and qualitative alterations occur in T-cell responses after skin contact with a hapten. Quantitatively, T cells proliferate and accumulate in DLNs (Kimber and Dearman, 1991). Qualitatively, T cells are activated and primed to produce IFN- $\gamma$ (Saint-Mezard et al., 2004). We found that DC-specific TAK1 deletion disrupted T-cell responses to TCE both quantitatively and qualitatively. The proliferation of lymphocytes in DLNs was abrogated in response to TCE when TAK1 was deleted in DCs (Figure 2A,B). In addition, the results showed that TAK1 deficiency in DCs decreased the percentage of total T cells, Th cells, Tc cells and Treg cells (Figure 3). These results were consistent with the finding that TAK1 is required in DCs to maintain homeostasis of T cells and promote Treg generation (Wang et al., 2012). Owing to the decreased total lymphocytes number in DLNs of the 80\% TCE group (Figure 2B), the cell counts of all abovementioned subsets of T cells were markedly decreased inMap3k $7^{\mathrm{DC}}$ mice compared to those in CON mice (Figure 3). Macrophages are another important subtype of antigen presenting cell (APC) in DLNs. We found that Map $3 k 7^{\mathrm{DC}}$ mice showed significantly increased percentage of macrophages (data not shown), which might be recruited to the peripheral lymphoid organ to remove the cellular debris that accumulates after TAK1 knock-out in DCs. However, as the main APC for sensitizers are DCs, the importance of macrophages is less prominent. Furthermore, consistent with the lower total lymphocytes number, the number of macrophages is also decreased in $M a p 3 k 7^{\mathrm{DC}}$ mice, which means considerably fewer macrophages could function in the immune response. The inhibitory effect of DC-specific TAK1 deficiency on the TCE-induced CHS was further supported by histopathological analysis of the ear sections (Figure 2C). We also found that the corresponding T-cell effector responses of the TCE-induced CHS, such as T-cell activation and cytokine secretion, are dependent on the intact TAK1 function in DCs (Figure 4). This indicates that TAK1 function in DC may be critical to regulate the T-cell populations during the 
development of the TCE-induced CHS response. Moreover, TAK1 maintains the DC populations and promotes DC survival and development (Wang et al., 2012), which infers that Map3k $7^{\mathrm{DC}}$ mice lack DCs to initiate the immune response to hapten-TCE in DLNs. These alternative explanations may account for the finding that DC-specific TAK1 deficient mice are unresponsive to TCE treatment.

The role of the NF- $\mathrm{KB}$ signaling pathway, particularly cytokine production in allergic inflammation, has been characterized (Blackwell et al., 1997). MAPKs represent an important signaling pathway in the immune response and cross-talk with NF-kB to regulate inflammation (Arbabi and Maier, 2002).

Therefore, we investigated the effect of MAPK and the NF- $\mathrm{BB}$ signaling pathway on TAK1 function in DCs to promote the TCE-induced CHS response. The results showed that TCE treatment significantly enhanced the phosphorylation of Jnk but not $\mathrm{p} 38$, Ikk $\alpha / \beta$ or IKB in CON mice, but DC-specific TAK1 deficiency impaired the TCE-mediated activation of Jnk in DLNs (Figure 5). IאB $\alpha$ and Ikk $\alpha / \beta$ phosphorylation were dramatically diminished in $M a p 3 k 7^{\mathrm{DC}}$ mice (Figure 5). It has been reported that TAK1 regulates the activities of the NF- $\kappa B$ pathway in splenic DCs in vivo (Wang et al., 2012). Our results showed that lack of TAK1 in DCs also inhibited NF-kB activity in peripheral lymph nodes. Although TCE had no impact on the phosphorylation level of Ikk $\alpha / \beta$ and I $\mathrm{KB}$, the suppression of NF- $\mathrm{KB}$ activity due to DC-specific TAK1 deficiency may result in inhibiting the downstream transcription of genes important for inflammatory and immune responses. This supposition requires further study to confirm conclusively, however. Collectively, these results provide evidence that the inhibitory effect of TAK1 deficiency in DC on the TCE-induced CHS response may be mediated by blocking the Jnk and NF- $\mathrm{B}$ signaling pathways in lymphocytes from DLNs.

Regulatory T cells, a subtype of $\mathrm{T}$ cells with anti-inflammatory properties, have important roles in the development and maintenance of immune tolerance (Josefowicz et al., 2012). In the CHS response, the 
development and proliferation of effector $\mathrm{CD} 8^{+} \mathrm{T}$ cells in DLNs were restricted by Treg cells (Kish et al., 2005; Ring et al., 2006). As such, the impaired TCE-induced CHS response in this study was likely to be attributed to the increased number of Treg cells, suppressing the immune responses. However, our results indicated that this may not be the case because the percentage and number of Treg cells in Map3k $7^{\mathrm{DC}}$ mice failed to expand during the TCE-induced CHS response, unlike that in the CON mice (Figure 3C). This finding suggested that in DCs, TAK1 function plays an important role in the TCE-induced CHS response through a regulatory T-cell- independent mechanism.

In summary, our study demonstrated that intact TAK1 function in DC plays a vital role in the development of the TCE-induced CHS response. The inhibitory effect of DC-specific TAK1 deficiency may be attributed, at least partially, to blocking the proliferation and T-cell priming functions in DLNs and skin inflammation in ears during the sensitization phase of to TCE-induced CHS response. Furthermore, these effects may be associated with impaired activation of the Jnk and NF- $\mathrm{kB}$ signaling pathways. Therefore, DC-specific targeting of TAK1 offers a potential approach to prevent and treat TCE-related occupational health hazard.

\section{Conflict of interest statement}

The authors have no conflicts to disclose.

\section{Acknowledgement}

This work was supported by the National Sciences Foundations of the People's Republic of China [grant number 81273112]. The authors would like to thank Xiaohong Hou, Dan Huang, Yuzheng Lian and Pei Qin for their excellent technical assistant in the animal testing.

\section{References:}


Adcock, I. M., Chung, K. F., Caramori, G. and Ito, K.,2006. Kinase inhibitors and airway inflammation. Eur J Pharmacol. 533, 118-32.

Ajibade, A. A., Wang, Q., Cui, J., Zou, J., Xia, X., Wang, M., Tong, Y., Hui, W., Liu, D., Su, B., Wang, H. Y. and Wang, R. F.,2012. TAK1 negatively regulates NF-kappaB and p38 MAP kinase activation in Gr-1+CD11b+ neutrophils. Immunity. 36, 43-54.

Anderson, S. E., Siegel, P. D. and Meade, B. J.,2011. The LLNA: A Brief Review of Recent Advances and Limitations. J Allergy (Cairo). 2011, 424203.

Arbabi, S. and Maier, R. V.,2002. Mitogen-activated protein kinases. Crit Care Med. 30, S74-S79.

Basketter, D. A., Gerberick, F. and Kimber, I.,2007. The local lymph node assay and the assessment of relative potency: status of validation. Contact Dermatitis. 57, 70-5.

Blackwell, T. S., Blackwell, T. R. and Christman, J. W.,1997. Impaired activation of nuclear factor-kappaB in endotoxin-tolerant rats is associated with down-regulation of chemokine gene expression and inhibition of neutrophilic lung inflammation. J Immunol. 158, 5934-40.

Chen, X. Y., Zhuang, Z. X., Wang, X. H. and Zhang, J. Z.,2006. Immune responses to trichloroethylene and skin gene expression profiles in Sprague Dawley rats. Biomed Environ Sci. 19, 346-52.

Choi, J. K., Oh, H. M., Lee, S., Park, J. W., Khang, D., Lee, S. W., Lee, W. S., Rho, M. C. and Kim, S. H.,2013. Oleanolic acid acetate inhibits atopic dermatitis and allergic contact dermatitis in a murine model. Toxicol Appl Pharmacol. 269, 72-80.

Christensen, A. D. and Haase, C.,2012. Immunological mechanisms of contact hypersensitivity in mice. APMIS. 120, 1-27.

Gerberick, G. F., Cruse, L. W. and Ryan, C. A., 1999. Local lymph node assay: differentiating allergic and irritant responses using flow cytometry. Methods. 19, 48-55. 
Gerberick, G. F., Cruse, L. W., Miller, C. M., Sikorski, E. E. and Ridder, G. M.,1997. Selective modulation of T cell memory markers CD62L and CD44 on murine draining lymph node cells following allergen and irritant treatment. Toxicol Appl Pharmacol. 146, 1-10.

Gorbachev, A. V. and Fairchild, R. L.,2001. Induction and regulation of T-cell priming for contact hypersensitivity. Crit Rev Immunol. 21, 451-72.

Hammaker, D. R., Boyle, D. L., Inoue, T. and Firestein, G. S.,2007. Regulation of the JNK pathway by TGF-beta activated kinase 1 in rheumatoid arthritis synoviocytes. Arthritis Res Ther. 9, R57.

Haneke, K. E., Tice, R. R., Carson, B. L., Margolin, B. H. and Stokes, W. S.,2001. ICCVAM evaluation of the murine local lymph node assay. Data analyses completed by the National Toxicology Program Interagency Center for the Evaluation of Alternative Toxicological Methods. Regul Toxicol Pharmacol. 34, 274-86.

Hariya, T., Hatao, M. and Ichikawa, H.,1999. Development of a non-radioactive endpoint in a modified local lymph node assay. Food Chem Toxicol. 37, 87-93.

Honda, T., Egawa, G., Grabbe, S. and Kabashima, K.,2013. Update of immune events in the murine contact hypersensitivity model: toward the understanding of allergic contact dermatitis. J Invest Dermatol. 133, 303-15.

Huang, H., Kamijima, M., Wang, H., Li, S., Yoshikawa, T., Lai, G., Huang, Z., Liu, H., Chen, J., Takeuchi, Y., Nakajima, T. and Li, L.,2006. Human herpesvirus 6 reactivation in trichloroethylene-exposed workers suffering from generalized skin disorders accompanied by hepatic dysfunction. J Occup Health. 48, 417-23.

Huang, Z., Yue, F., Yang, X., Xia, L., Chen, C., Qiu, X., Huang, J., Li, L., Kamijima, M., Nakajima, T. and Huang, H.,2012. Upregulation of calprotectin and downregulation of retinol binding protein in the 
serum of workers with trichloroethylene-induced hypersensitivity dermatitis. J Occup Health. 54, 299-309.

Humphreys, N. E., Dearman, R. J. and Kimber, I.,2003. Assessment of cumulative allergen-activated lymph node cell proliferation using flow cytometry. Toxicol Sci. 73, 80-9.

Jakob, T., Ring, J. and Udey, M. C.,2001. Multistep navigation of Langerhans/dendritic cells in and out of the skin. J Allergy Clin Immunol. 108, 688-96.

Josefowicz, S. Z., Lu, L. F. and Rudensky, A. Y.,2012. Regulatory T cells: mechanisms of differentiation and function. Annu Rev Immunol. 30, 531-64.

Kajino-Sakamoto, R., Inagaki, M., Lippert, E., Akira, S., Robine, S., Matsumoto, K., Jobin, C. and Ninomiya-Tsuji, J.,2008. Enterocyte-derived TAK1 signaling prevents epithelium apoptosis and the development of ileitis and colitis. J Immunol. 181, 1143-52.

Kamijima, M., Wang, H., Huang, H., Li, L., Shibata, E., Lin, B., Sakai, K., Liu, H., Tsuchiyama, F., Chen, J., Okamura, A., Huang, X., Hisanaga, N., Huang, Z., Ito, Y., Takeuchi, Y. and Nakajima, T.,2008. Trichloroethylene causes generalized hypersensitivity skin disorders complicated by hepatitis. J Occup Health. 50, 328-38.

Kamijima, M., Hisanaga, N., Wang, H. and Nakajima, T.,2007. Occupational trichloroethylene exposure as a cause of idiosyncratic generalized skin disorders and accompanying hepatitis similar to drug hypersensitivities. Int Arch Occ Env Hea. 80, 357-370.

Kaneko, T., Saegusa, M., Tasaka, K. and Sato, A.,2000. Immunotoxicity of trichloroethylene: a study with MRL-lpr/lpr mice. J Appl Toxicol. 20, 471-5.

Kaplan, D. H., Igyártó, B. Z. and Gaspari, A. A.,2012. Early immune events in the induction of allergic contact dermatitis. Nat Rev Immunol. 12, 114-124. 
Kawai, T. and Akira, S.,2011. Toll-like receptors and their crosstalk with other innate receptors in infection and immunity. Immunity. 34, 637-50.

Kimber, I., Dearman, R. J., Basketter, D. A., Ryan, C. A. and Gerberick, G. F.,2002. The local lymph node assay: past, present and future. Contact Dermatitis. 47, 315-28.

Kimber, I. and Dearman, R. J.,1991. Investigation of lymph node cell proliferation as a possible immunological correlate of contact sensitizing potential. Food Chem Toxicol. 29, 125-9.

Kish, D. D., Gorbachev, A. V. and Fairchild, R. L.,2005. CD8+ T cells produce IL-2, which is required for $\mathrm{CD}(4+) \mathrm{CD} 25+\mathrm{T}$ cell regulation of effector CD8+ T cell development for contact hypersensitivity responses. J Leukoc Biol. 78, 725-35.

Ma, F. Y., Tesch, G. H., Ozols, E., Xie, M., Schneider, M. D. and Nikolic-Paterson, D. J.,2011. TGF-beta1-activated kinase-1 regulates inflammation and fibrosis in the obstructed kidney. Am J Physiol Renal Physiol. 300, F1410-21.

Ministry of Health of the People's Republic of China,2007. Diagnostic criteria of occupational medicamentose-like dermatitis due to trichloroethylene, Ed.

Nakayama, H., Kobayashi, M., Takahashi, M., Ageishi, Y. and Takano, T.,1988. Generalized eruption with severe liver dysfunction associated with occupational exposure to trichloroethylene. Contact Dermatitis. 19, 48-51.

Ninomiya-Tsuji, J., Kishimoto, K., Hiyama, A., Inoue, J., Cao, Z. and Matsumoto, K.,1999. The kinase TAK1 can activate the NIK-I kappaB as well as the MAP kinase cascade in the IL-1 signalling pathway. Nature. 398, 252-6.

Ninomiya-Tsuji, J., Kajino, T., Ono, K., Ohtomo, T., Matsumoto, M., Shiina, M., Mihara, M., Tsuchiya, M. and Matsumoto, K.,2003. A Resorcylic Acid Lactone, 5Z-7-Oxozeaenol, Prevents Inflammation by 
Inhibiting the Catalytic Activity of TAK1 MAPK Kinase Kinase. J Biol Chem. 278, 18485-18490.

OECD,2010. Skin Sensitisation: Local Lymph Node Assay: BrdU-ELISA. OECD Guideline for the

Testing of Chemicals No. 442B, Paris. http://www.oecd.org/env/testguidelines

Omori, E., Matsumoto, K., Sanjo, H., Sato, S., Akira, S., Smart, R. C. and Ninomiya-Tsuji, J.,2006. TAK1 is a master regulator of epidermal homeostasis involving skin inflammation and apoptosis. J Biol Chem. 281, 19610-7.

Rajasekaran, K., Chu, H., Kumar, P., Xiao, Y., Tinguely, M., Samarakoon, A., Kim, T. W., Li, X., Thakar, M. S., Zhang, J. and Malarkannan, S.,2011. Transforming growth factor-beta-activated kinase 1 regulates natural killer cell-mediated cytotoxicity and cytokine production. J Biol Chem. 286, 31213-24.

Ring, S., Schafer, S. C., Mahnke, K., Lehr, H. A. and Enk, A. H.,2006. CD4+ CD25+ regulatory T cells suppress contact hypersensitivity reactions by blocking influx of effector T cells into inflamed tissue.

Eur J Immunol. 36, 2981-92.

Sailstad, D. M., Hattan, D., Hill, R. N. and Stokes, W. S.,2001. ICCVAM evaluation of the murine local lymph node assay. The ICCVAM review process. Regul Toxicol Pharmacol. 34, 249-57.

Saint-Mezard, P., Rosieres, A., Krasteva, M., Berard, F., Dubois, B., Kaiserlian, D. and Nicolas, J. F.,2004. Allergic contact dermatitis. Eur J Dermatol. 14, 284-95.

Saint-Mezard, P., Berard, F., Dubois, B., Kaiserlian, D. and Nicolas, J. F.,2004. The role of CD4+ and CD8+ T cells in contact hypersensitivity and allergic contact dermatitis. Eur J Dermatol. 14, 131-8.

Sakurai, H., Shigemori, N., Hasegawa, K. and Sugita, T.,1998. TGF-beta-activated kinase 1 stimulates NF-kappa B activation by an NF-kappa B-inducing kinase-independent mechanism. Biochem Biophys Res Commun. 243, 545-9.

Sakurai, H., Miyoshi, H., Toriumi, W. and Sugita, T.,1999. Functional interactions of transforming growth 
factor beta-activated kinase 1 with IkappaB kinases to stimulate NF-kappaB activation. J Biol Chem.

274, 10641-8.

Sakurai, H.,2012. Targeting of TAK1 in inflammatory disorders and cancer. Trends Pharmacol Sci. 33, $522-30$.

Sato, S.,2006. TAK1 is indispensable for development of T cells and prevention of colitis by the generation of regulatory T cells. Int Immunol. 18, 1405-1411.

Shirakabe, K., Yamaguchi, K., Shibuya, H., Irie, K., Matsuda, S., Moriguchi, T., Gotoh, Y., Matsumoto, K. and Nishida, E.,1997. TAK1 mediates the ceramide signaling to stress-activated protein kinase/c-Jun N-terminal kinase. J Biol Chem. 272, 8141-4.

Sikorski, E. E., Gerberick, G. F., Ryan, C. A., Miller, C. M. and Ridder, G. M.,1996. Phenotypic analysis of lymphocyte subpopulations in lymph nodes draining the ear following exposure to contact allergens and irritants. Fundam Appl Toxicol. 34, 25-35.

Takeyoshi, M., Noda, S., Yamasaki, K. and Kimber, I.,2006. Advantage of using CBA/N strain mice in a non-radioisotopic modification of the local lymph node assay. J Appl Toxicol. 26, 5-9.

van den Berg, F. A., Baken, K. A., Vermeulen, J. P., Gremmer, E. R., van Steeg, H. and van Loveren, H.,2005. Use of the local lymph node assay in assessment of immune function. Toxicology. 211, $107-14$

Wang, Y., Huang, G., Vogel, P., Neale, G., Reizis, B. and Chi, H.,2012. Transforming growth factor beta-activated kinase 1 (TAK1)-dependent checkpoint in the survival of dendritic cells promotes immune homeostasis and function. Proceedings of the National Academy of Sciences. 109, E343-E352.

Watanabe, H., Tohyama, M., Kamijima, M., Nakajima, T., Yoshida, T., Hashimoto, K. and Iijima, M.,2010. Occupational trichloroethylene hypersensitivity syndrome with human herpesvirus-6 and 
cytomegalovirus reactivation. Dermatology. 221, 17-22.

Watanabe, H.,2011. Hypersensitivity syndrome due to trichloroethylene exposure: A severe generalized skin reaction resembling drug-induced hypersensitivity syndrome. The Journal of Dermatology. 38, 229-235.

Xu, X., Yang, R., Wu, N., Zhong, P., Ke, Y., Zhou, L., Yuan, J., Li, G., Huang, H. and Wu, B.,2009. Severe hypersensitivity dermatitis and liver dysfunction induced by occupational exposure to trichloroethylene. Ind Health. 47, 107-12.

Yongshun, H. and Hanlin, H.,2010. Research progress on immune injury resulted from occupational medicamentose- like dermatitis induced by trichloroethylene. China Occupational Medicine, $157-159+162$.

Zhao, Y. G., Wang, Y., Hao, W. and Wan, Y. Y.,2011. An essential role for TAK1 in the contact hypersensitivity response. Cell Mol Immunol. 8, 315-24. 


\section{Figure legends:}

Figure 1. TAK1 deletion efficiency in DCs of $M a p 3 k 7^{\mathrm{DC}}$ mice. TAK1 mRNA expression level in splenic DCs and $\mathrm{CD}^{+} \mathrm{T}$ cells of $\mathrm{CON}$ and $M a p 3 k 7^{\mathrm{DC}}$ mice. The bars represented mean $\pm \mathrm{SD}(\mathrm{n}=4) . *^{*} p<0.01$ compared with CON mice.

Figure 2. Abolished TCE-induced CHS response in Map $3 k 7^{\mathrm{DC}}$ mice. (A) LLNA: BrdU-ELISA was performed as mentioned in the Materials and Methods section. Results of LLNA were expressed as SI, SI=BrdU labeling index of the treated group/ BrdU labeling index of AOO. The decision process regards a result as positive when $\mathrm{SI} \geq 1$ 1.6. (B)At 24h after BrdU injection, lymphocytes from DLNs of CON and Map $3 k 7^{\mathrm{DC}}$ mice were collected and the total lymphocytes numbers were counted. (C) Histopathological analysis of ear sections from CON and Map $3 k 7^{\mathrm{DC}}$ mice sensitized with $\mathrm{AOO}$ or $80 \% \mathrm{TCE}$, as described in (A). Representative photomicrographs of ear sections were stained with hematoxylin and eosin (original magnification: $\times 200)$. The bars represent mean $\pm \mathrm{SD}(\mathrm{n}=6) .{ }^{* *} p<0.01$ compared with CON mice, ${ }^{\# \#} p$ $<0.01$ compared with the AOO vehicle control group.

Figure 3. Map $3 k 7^{\mathrm{DC}}$ mice showed diminished T-cell populations during the sensitization phase of the TCE-induced CHS response. (A) Flow cytometry analysis of T cells $\left(\mathrm{CD}^{+}\right)$and B cells $\left(\mathrm{B} 220^{+}\right)$in DLNs from CON and Map3k $7^{\mathrm{DC}}$ mice in indicated groups. (Right) The percentages and numbers of $\mathrm{T}$ and $\mathrm{B}$ cells in DLNs were plotted. (B) Flow cytometry analysis of helper T cells $\left(\mathrm{CD} 4^{+}\right)$and cytotoxic $\mathrm{T}$ cells $\left(\mathrm{CD} 8^{+}\right)$ in DLNs from CON and Map3k $37^{\mathrm{DC}}$ mice in indicated groups. (Right) The percentages and numbers of $\mathrm{CD}^{+}$and $\mathrm{CD} 8^{+} \mathrm{T}$ cells in DLNs were plotted. (C) Flow cytometry analysis of CD25+ $\mathrm{Foxp}^{+} \mathrm{CD}^{+}$Treg cells in the DLNs from CON and Map3k $7^{\mathrm{DC}}$ mice in indicated groups. (Right) The percentages and numbers of Treg cells were plotted. The bars represent mean \pm SD $(\mathrm{n}=6) . * p<0.05, * * p<0.01$ compared with CON mice; ${ }^{\#} p<0.05,{ }^{\# \#} p<0.01$ compared with the AOO vehicle control group. 
Figure 4. Diminished activation and cytokine secretion of $\mathrm{CD}^{+}$and $\mathrm{CD} 8^{+} \mathrm{T}$ cells in the $80 \%$ TCE-treated Map $3 k 7^{\mathrm{DC}}$ mice. Flow cytometry analysis of $\mathrm{CD} 44$ and CD62L expression on $\mathrm{CD}^{+}(\mathrm{A})$ and $\mathrm{CD} 8^{+}(\mathrm{B}) \mathrm{T}$ cells in DLNs of indicated mice in the AOO and 80\% TCE groups. (Right)The proportions of CD62L $\mathrm{L}^{\text {low }}$ CD44 ${ }^{\text {high }}$ activated $\mathrm{T}$ cells were plotted. IFN- $\gamma$ and IL-4 secreted by $\mathrm{CD}^{+}(\mathrm{C})$ and $\mathrm{CD} 4^{+}(\mathrm{D}) \mathrm{T}$ cells in the DLNs of indicated mice were assessed by intracellular staining. (Right) The frequency of IFN- $\gamma$-producing $\mathrm{CD} 8{ }^{+}$and $\mathrm{CD} 4{ }^{+} \mathrm{T}$ cells were plotted. The bars represent mean $\pm \mathrm{SD}(\mathrm{n}=6) . * p<0.05, * * p<0.01$ compared with CON mice.

Figure 5. Effect of TAK1deletion in DCs on the phosphorylation of p38, Jnk and NF-kB. Western blot of lysates of lymphocytes in DLNs from CON and Map3k $7^{\mathrm{DC}}$ mice, in either the AOO (A) or $80 \%$ TCE (T) group, analyzed for phosphorylation of p38 (p-p38), Jnk (p-Jnk), IкB $\alpha(p-I \kappa B \alpha)$ and Ikk $\alpha / \beta(p-I k k \alpha / \beta)$ and expression of total $\mathrm{p} 38$, Jnk, IкB $\alpha$ and $\beta$-actin (loading control). Data represent three independent experiments. The bars represent mean $\pm \mathrm{SD}(\mathrm{n}=3) .{ }^{* *} p<0.01$ compared with CON mice in the AOO group. 
Figure 1
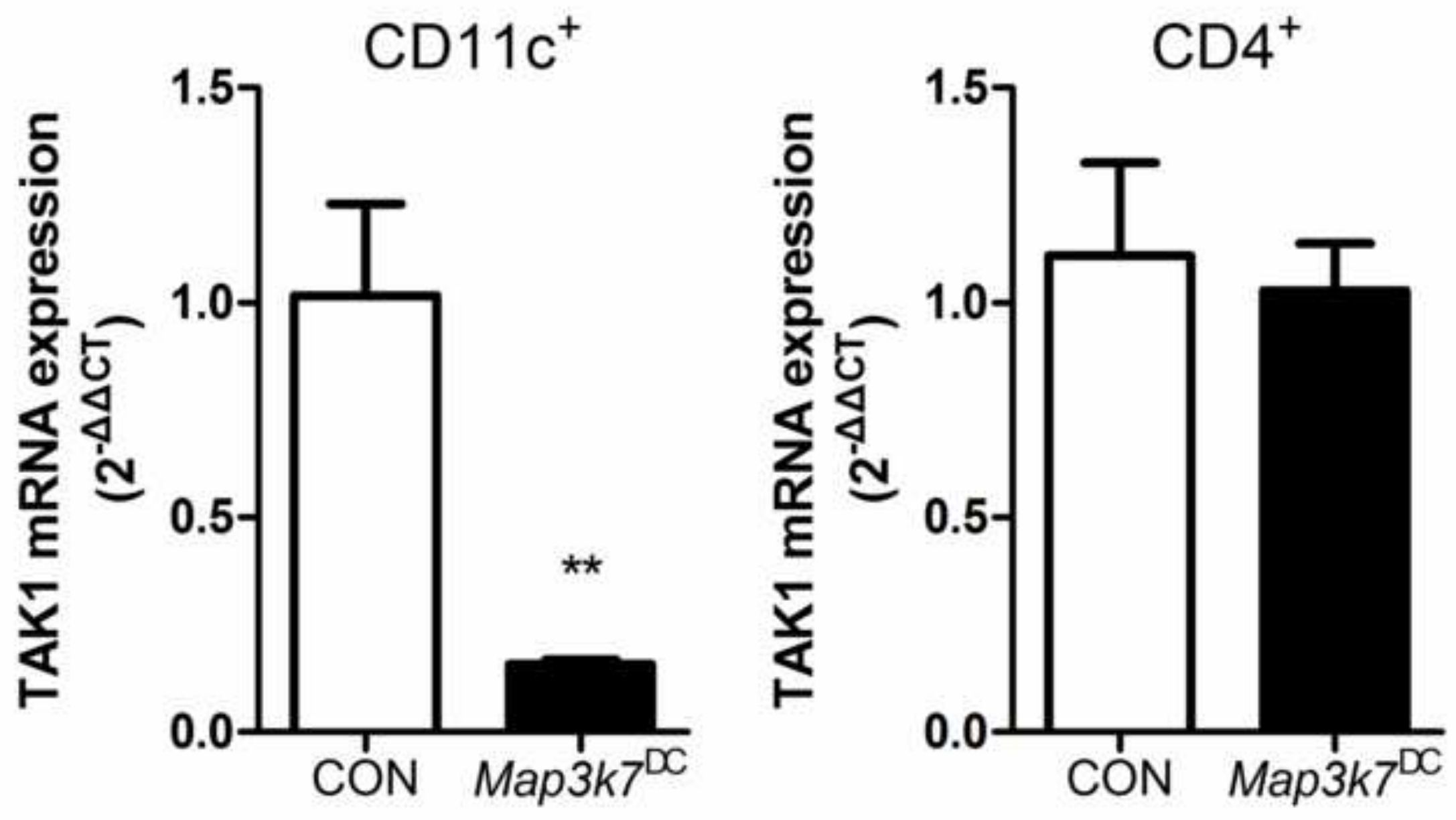
Figure 2
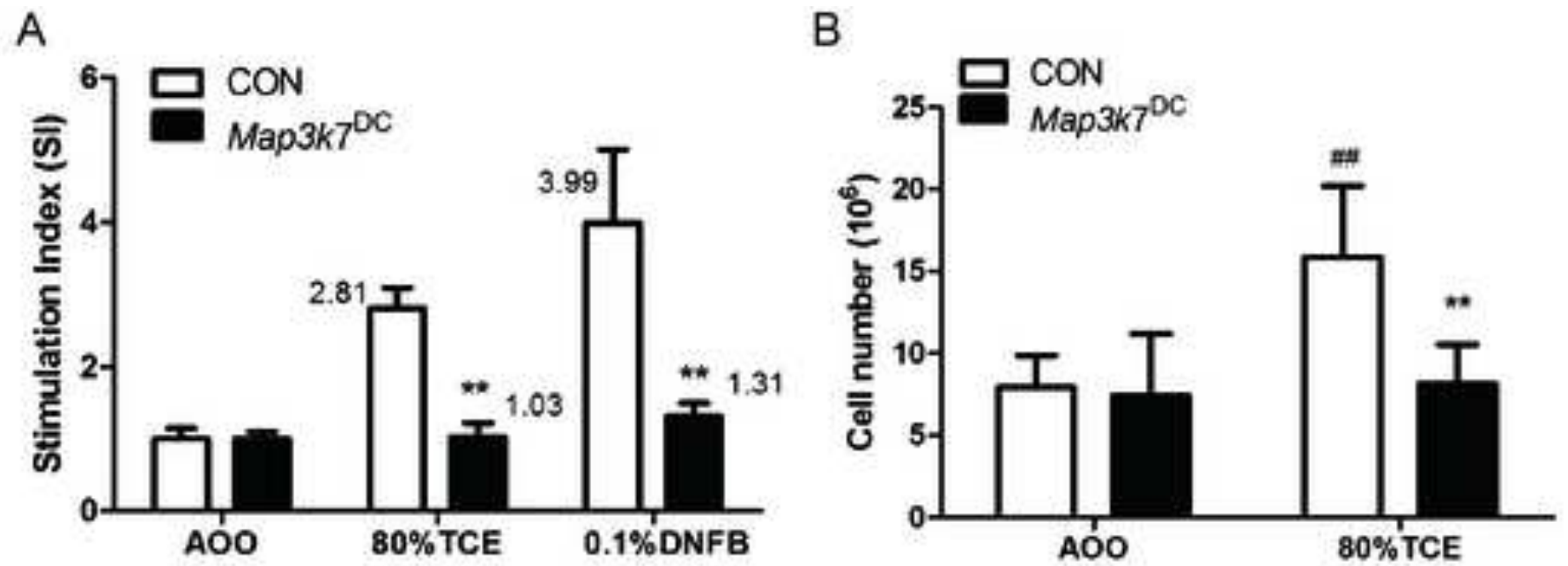

C

$\mathrm{AOO}$

$80 \%$ TCE

CON



$\operatorname{Map} 3 k 7^{\mathrm{DC}}$

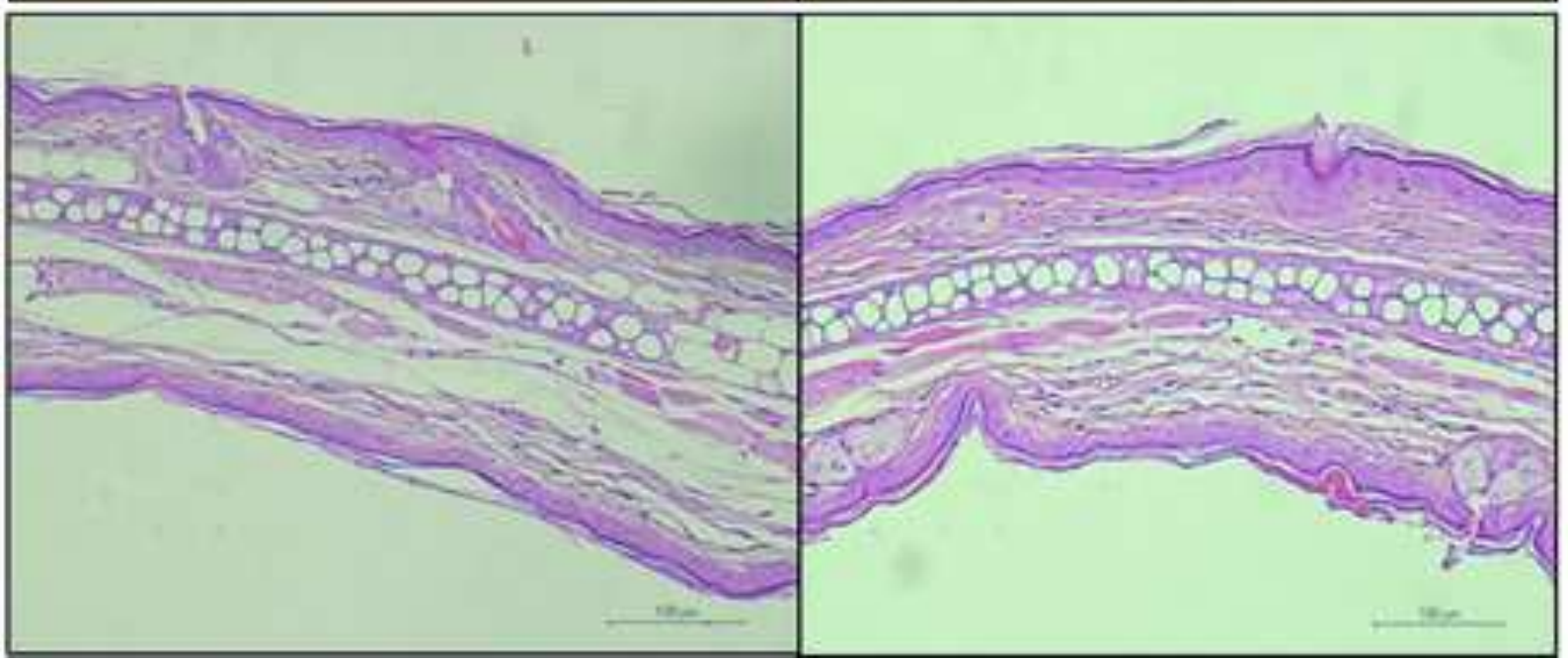


Figure 3

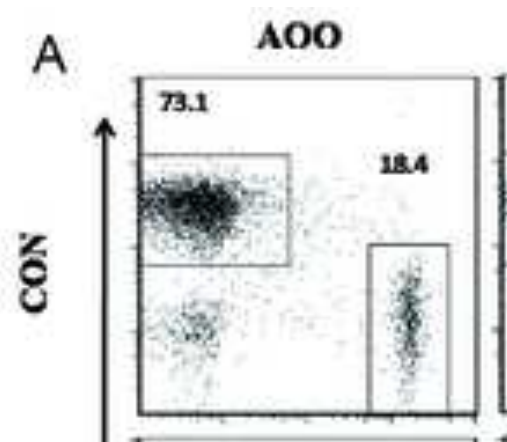

$80 \%$ TCE
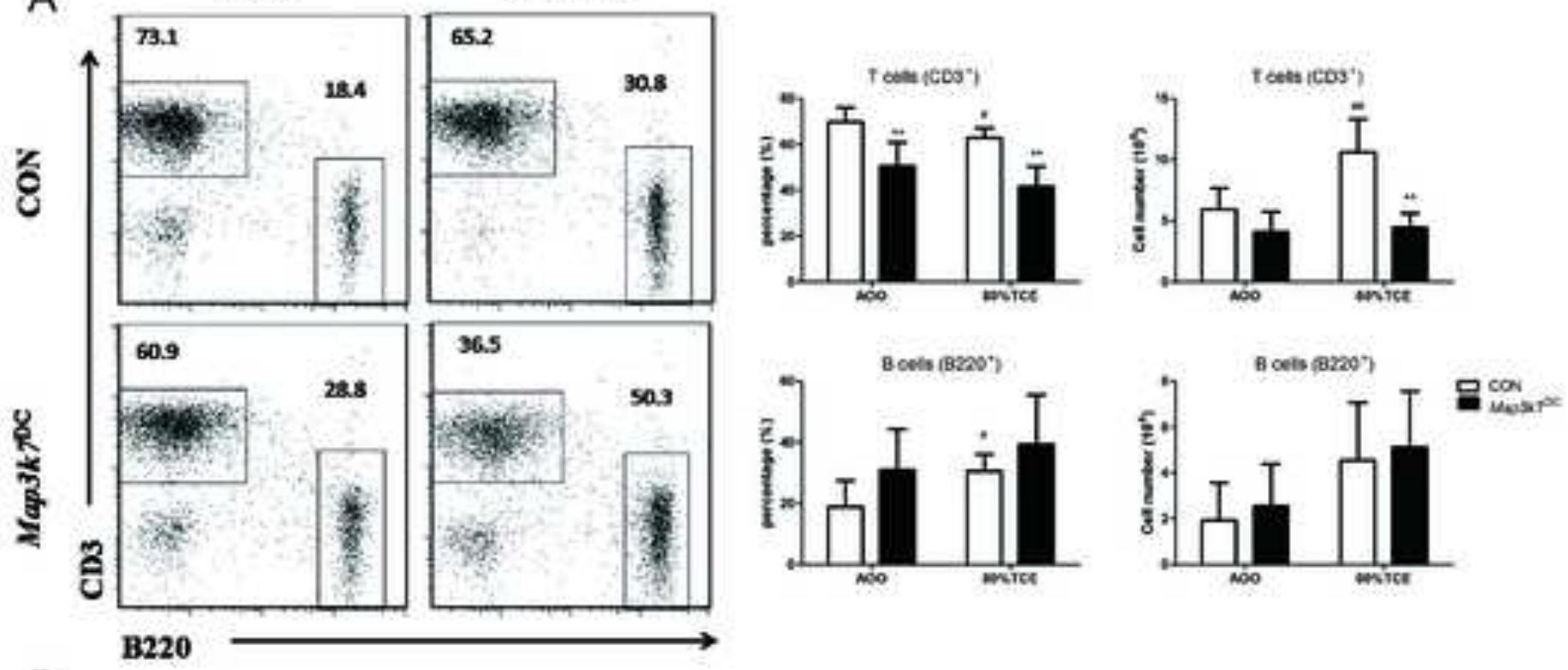

B

AOO
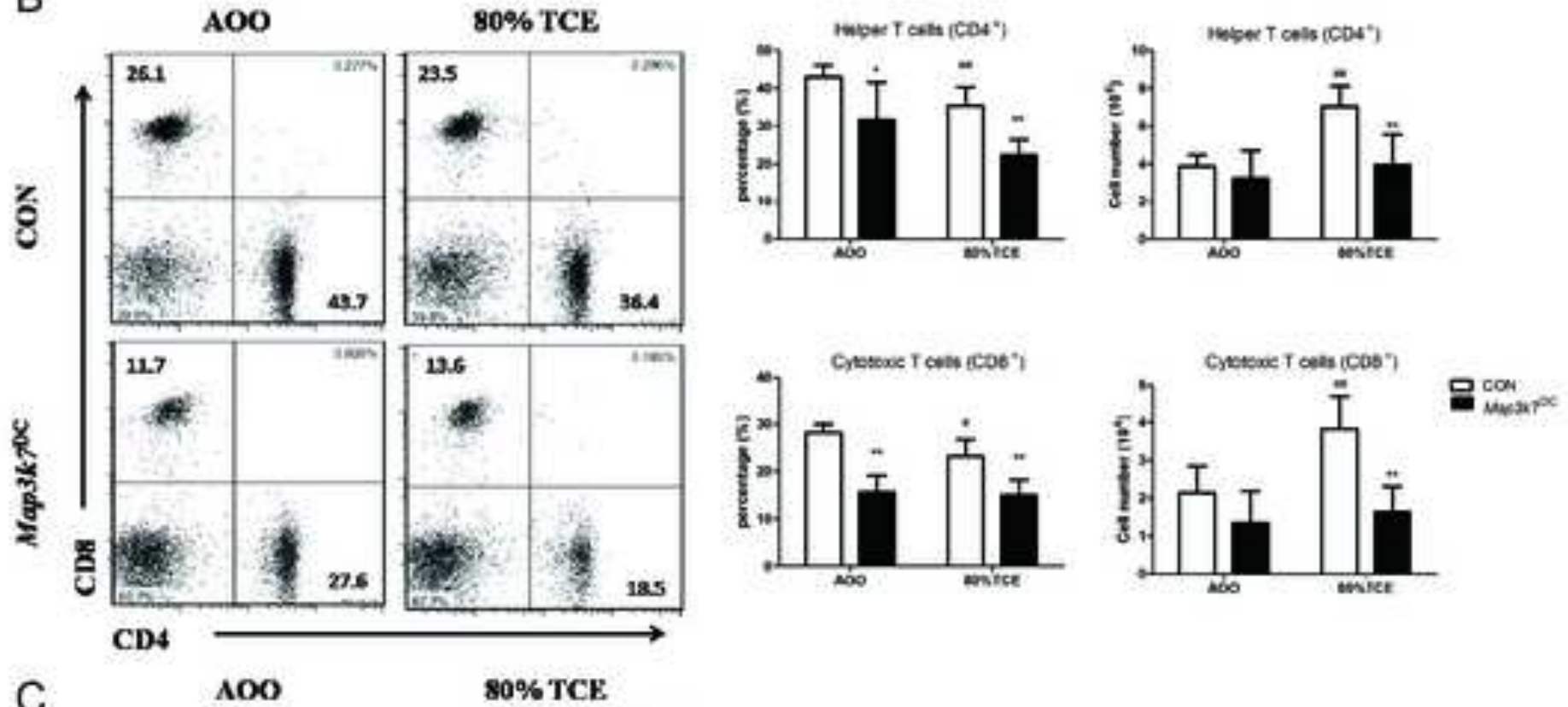

C

Gated on CD4*
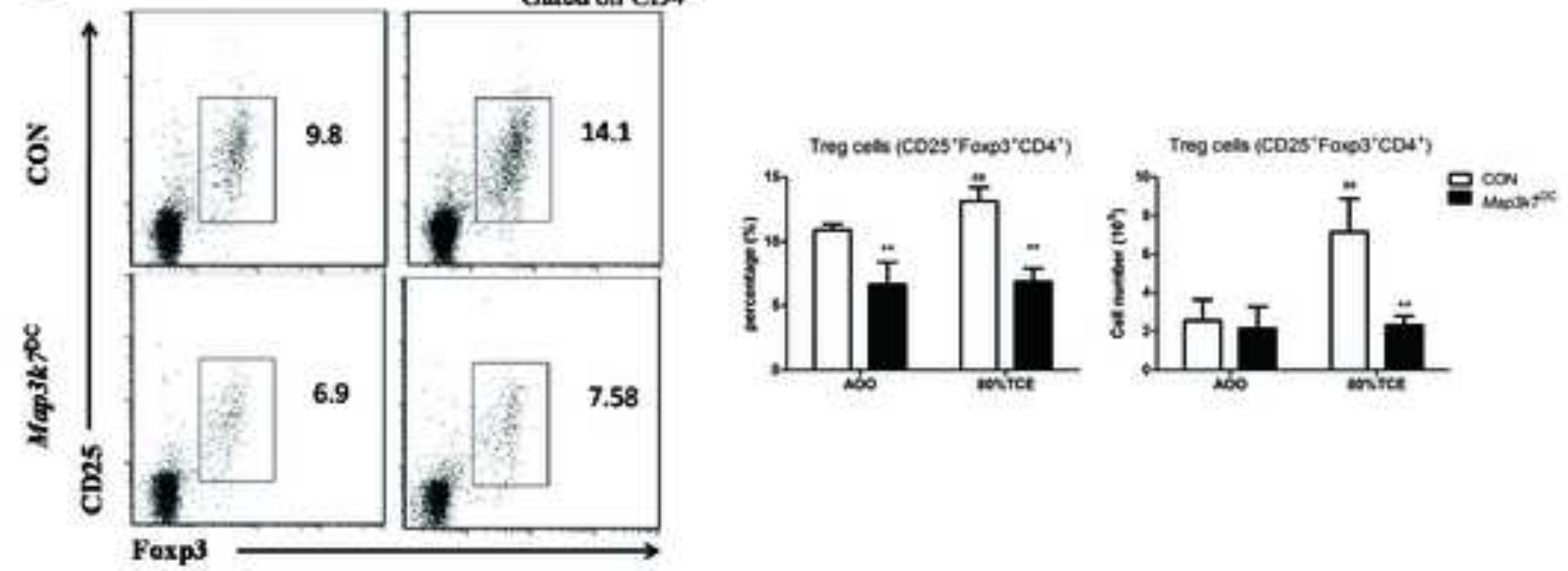
Figure 4



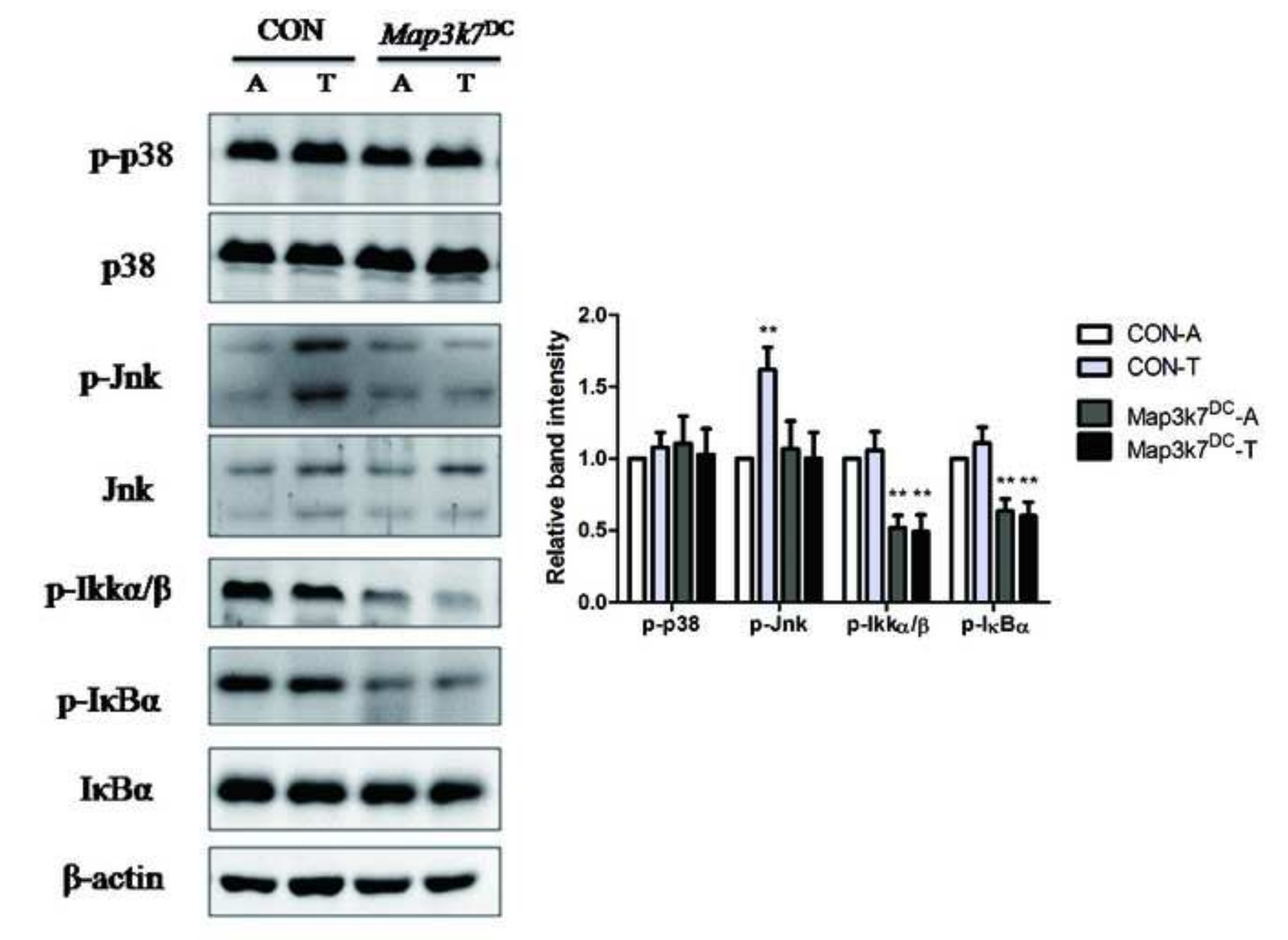

